\title{
Travels in aspects of their functions and pedagogical values
}

\section{Podróże w aspekcie ich funkcji i wartości pedagogicznych}

\author{
Agnieszka Katarzyna Gębora \\ Higher School of Wholesome Education and Social Sciences \\ 21 Kamińskiego St., 90-229 Łódź, Poland \\ E-mail address: k.gebora@wp.pl
}

Podróżować to żyć

Hans Christian Andersen

\begin{abstract}
Travels influence on comprehensive human development, they are source of knowledge, create possibility of satisfaction of one basic need which is the need of cognition. Tourism education gives chances for people to take part in culture dialogues, educate in a humanistic way, breaks barrier between nations and societies of different regions of the world. Travel, apart from place, time and aims and other circumstances which every trip is accompanied with, gives the chance for development.
\end{abstract}

Keywords: travel; function; value; education; pedagogical aspect

\section{STRESZCZENIE}

Podróże wpływają na wszechstronny rozwój człowieka, stanowią źródło wiedzy i stwarzają możliwość zaspokojenia jednej z podstawowych potrzeb jaką jest potrzeba poznawcza. Edukacja turystyczna daje szansę udziału w dialogu kultur, wychowuje humanistycznie, przełamuje bariery nieufności miedzy ludźmi, narodami i społeczeństwami różnych regionów świata. Podróż, niezależnie od czasu, miejsca, celu i innych okoliczności towarzyszących wędrówce, daje szansę na rozwój.

Słowa kluczowe: Podróż; funkcja; wartość; kształcenie; aspekt pedagogiczny

\section{INTRODUCTION}

Podróże, wyprawy czy peregrynacje należą do najbardziej pierwotnych form aktywności człowieka. Już w odległych czasach ciekawość świata, potrzeba przeżyć duchowych i poznawczych popychała ludzi do wędrówek. Powyższe motywy sprawiały, że zaczęły się 
uwidaczniać takie postawy wobec podróżowania, które dziś traktujemy jako turystykę edukacyjną.

Podróż ( $\mathrm{z}$ łaciny zwana peregrynacją, z francuskiego wojażem), to zmiana miejsca pobytu na odległe, to przebywanie drogi do jakiegoś odległego miejsca.

Aspekt ontyczny podróży wyraża się poprzez jej zasadniczy podmiot, czyli człowieka podróżującego. Podróże są, zwłaszcza współcześnie, sposobem bycia człowieka, sposobem realizowania przez niego różnych wartości, sposobem poznawania świata, jego przewidywania, bycia z innymi; są realizacją wolności. (Köb, 2005)

Badania nad podróżą osób dorosłych, wykazały, iż dla większości uczestników, podróż wiąże się z silnymi przeżyciami i doznaniami, które mogą być pomocne w trudnych sytuacjach życiowych. Badani powracają do wspomnień w chwili zmęczenia, zniechęcenia, czy zamiłowania. Przywołują wtedy urodę krajobrazów, piękno zabytków, czują zapach i smak potraw. Poprawia się nastrój, wzmacnia kondycja psychiczna. Powyższe doznania „ odświeżają myśli, oczyszczają umysł”.(Czerniawska, 2001)

W literaturze przedmiotu wymienia się najczęściej następujące funkcje podróży:

- Funkcja poznawcza,

- Funkcja kształcąca / edukacyjna,

- Funkcja wychowawcza / socjalizacyjna,

- Funkcja społeczna / integracyjna,

- Funkcja estetyczna / kulturalna,

- Funkcja emocjonalna / duchowa,

- Funkcja zdrowotna / rekreacyjna / wypoczynkowa / rozrywkowa / sportowa / resocjalizacyjna,

- Funkcja ekonomiczna/gospodarcza.

Już w starożytnej Grecji uprawiano podróże w celach poznawczych i samokształceniowych. Poeci sławili męstwo i odwagę podróżników. Starożytni Rzymianie, którzy odbywali głównie podróże lądowe dzięki dobrym drogom, które łączyły ich rozległe prowincje, również traktowali wędrówki jako element samokształcenia.

Warto zaznaczyć, iż prawie wszystkie wielkie cywilizacje powstały i rozwinęły się wśród oceanów i mórz, nad brzegami i dopływami wielkich rzek, w pobliżu wielkich jezior. Woda miała fundamentalne znaczenie dla rozwoju gospodarczego i kulturalnego krajów. (Krawczyk, 2007)

Wśród najbardziej znanych kultur morskich można wymienić następujące:

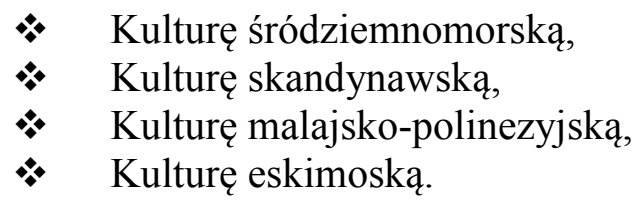

W basenie Morza Śródziemnego ukształtowała się i rozwinęła starożytna Grecja i starożytny Rzym. Kultura antycznych państw do dziś zachowała trwałą wartość, daje szansę czerpania inspiracji, stanowi tworzywo myślowe, jest niewyczerpanym źródłem wiedzy, szczególnie dla narodów europejskich.

Morze to rozległa, tania i bezpośrednia sieć dróg komunikacyjnych pomiędzy różnymi częściami świata, to baza kontaktów między państwami, stanowi niewyczerpany teren eksploatacji gospodarczej. Rozbudowa floty i portów nadmorskich miast z licznymi 
instytucjami handlowymi, gospodarczymi i kulturalnymi, nowe rynki zbytu dają w perspektywie szansę na rozwój. Morze to również znakomity teren i źródło rozwoju różnych form wypoczynku, rozrywki, lecznictwa, sportu, rekreacji i turystyki.

Wśród pisarzy i społeczników, dla których podróż nad morze stanowiła źródło refleksji intelektualnej, można wymienić np. S. Żeromskiego. Pisarz przedstawił najbardziej dojrzałą i pełną wizję społecznej funkcji morza. W swojej koncepcji podkreślał idee harmonijności pomiędzy stopniem opanowania morza przez człowieka, a stanem jego osiągnięć na polu cywilizacji i kultury. (Krawczyk, 2007) Zdaniem S. Żeromskiego, bogactwo morza daje szansę rozwoju gospodarki, zdrowia, wypoczynku, co stanowi podstawę do osiągnięcia wyższego poziomu w dziedzinie ekonomicznej i zdrowotnej dla polskiego społeczeństwa. Poglądy autora „Wiatru od morza” (Żeromski, 1955) wpisują się w nurt literatury marynistycznej. W duchu Żeromskiego pisał m.in. W. Orkan:

\begin{abstract}
„W przestronnych sosnowych lasach Helu powinny powstać sanatoria dla dzieci, zagościć się - już nie koczujące jak w Gdyni (...), powinny stanąć kolonie nauczycielskie, wille dla wypoczynku inteligencji pracującej (...). Słowem Hel ma wszystkie dane na to, aby stać się już w bliskiej przyszłości riwierą polską". (Orkan, 1926)
\end{abstract}

W literaturze marynistycznej pojawiają się inne koncepcje, zasadniczo różne od poglądów S. Żeromskiego, czy W. Orkana, np. u J. Conrada, mistrza w kreowaniu charakterów ludzi morza- odwiecznych podróżników. Pisarz fascynował się poszukiwaniem sensu i modelu życia, znalazł je na statku żaglowym.

J. Conrad był przedstawicielem nurtu, w którym przedstawiano sobie dwa światy: natury i kultury, morze traktowano jako miejsce ucieczki od wrogiej cywilizacji a nie tylko jako źródło cywilizacyjno-kulturowych osiągnięć człowieka

Kontynuatorem nurtu marynistycznego był pisarz młodopolski M. Zaruski, który w swej twórczości eksponował wątek antynomii natury i kultury jako dwóch sfer życia dla siebie wrogich. Konflikt miedzy człowiekiem a cywilizacją to wyraz metafizycznej sprzeczności miedzy jednostką a jej wytworami.

Mariusz Zaruski był postacią w stylu ludzi renesansu. Jak podkreśla B. Miazgowski, Zaruski był patriotą, konspiratorem, zesłańcem, rosyjskim marynarzem i polskim poetą, polskim ułanem, taternikiem i malarzem, generałem, świetnym organizatorem i społecznikiem, przyjacielem i wychowawcą młodzieży, żeglarzem. Miał dwie największe pasje swojego życia: morze i góry. Jako marynarz, a potem kapitan statków żaglowych pływał po Morzu Czarnym i Śródziemnym, Oceanie Spokojnym, Atlantyckim, Indyjskim i Lodowatym. Fascynował go żywioł morza, świat żeglarzy, ludzi obcujących bezpośrednio z przyrodą, mocno związanych ze współtowarzyszami rejsów. (Miazgowski, 1958)

M. Zaruski zachęcał społeczeństwo polskie do rozwoju następujących kierunków marynistyki w Polsce:

Wychowania morskiego młodzieży

Rozwoju żeglarstwa,

Budowy ośrodków żeglarskich nad morzem, jeziorami i rzekami,

Utrzymywanie morskich statków wycieczkowych,

Zakładanie jacht-klubów, domów wycieczkowych,

Opieki nad kulturą kaszubską,

Zakładanie towarzystw i przedsiębiorstw tworzących infrastrukturę gospodarki morskiej. (Sługocki, 1988) 
M. Zaruski uważał, że morza i oceany mogą odegrać w życiu człowieka ogromną rolę, jeśli pozostaną one wartością autoteliczną, a nie będą traktowane wyłącznie instrumentalnie. Natura, według autora, jest światem odrębnym, transcendentnym samym w sobie, posiada własny rytm i rządzi się odrębnymi prawami. Tylko natura nieskażona kulturą jest nieśmiertelna.

Jak pisze Z. Krawczyk, na gruncie polskiej literatury marynistycznej, M. Zaruski był pionierem, łączył uwielbienie dla morza $z$ umiłowaniem Tatr. W licznych podróżach dostrzegał walor poznawczy, kształcący, wychowawczy, społeczny, kulturowy, estetyczny i duchowy. (Krawczyk, 1970)

Zdaniem M. Dzięgielewskiej uczestnictwo w podróży naukowej wiąże się też z poznaniem zachowań indywidualnych i zbiorowych, poznaniem innych środowisk, nowych kultur, obyczajów i zwyczajów. Różnorodne doświadczenia stają się czynnikami integrującymi osobowość, są inspiracją do doskonalenia siebie i relacji międzyludzkich. Stanowią źródło sukcesów lub zachętę do naśladowania dobrych wzorów i przykładów, do analizowania przyczyn, niepowodzeń. Dają szansę wprowadzania tych rozwiązań, które są racjonalne i mogą przyczynić się do postępu w danej dziedzinie.

Edukacja winna przygotować człowieka do „zrozumienia problemów środowiska lokalnego, regionalnego, własnego narodu i powiązać je z problemami całej ludzkości." U. A. Domżał, wśród problemów współczesnego świata wskazuje m.in. na: ochronę dziedzictwa kulturowego i naturalnego wszystkich grup społecznych. Stąd nowe wyzwania w zakresie edukacji. (Domżal, 2009)

Podróże mają walor edukacyjny w zakresie wiedzy i umiejętności. Pozwalają zwiększyć doświadczenie, pogłębić zaradność życiową, zachęcić do otwartości na inne kraje, kultury i narody, wzmacniają motywacje do nauki języków obcych, poprawiają kondycje psychofizyczną i intelektualną. (Woźnicka, 2001)Podróże przełamują pewne stereotypy dotyczące widzenia mieszkańców innych krajów. (Juraś-Krawczyk, 2001)

Współcześnie wirtualna podróż może odbyć w sieci. Jak twierdzi A. K. Gębora, media stwarzają współczesnemu człowiekowi ogromne szanse na intensywny rozwój. Zdaniem autorki, , przepływ informacji przez sieć internetową do środowisk oświatowych przyspieszył proces otwarcia się na oświatowe trendy edukacyjne. W związku z tym wymiana kulturowa stała się faktem. (Gębora, 2009)

Zdaniem L. Turosa, podróże są atrakcyjnymi i funkcjonalnymi formami dydaktycznymi systemu oświaty i wychowania. Umożliwiają osobiste, bezpośrednie i aktywne poznanie rzeczywistości społecznej, kulturowej, przyrodniczej lub cywilizacyjnej. Dają też szanse konfrontacji teorii z praktyką. Pozwalają uzyskać cenne doświadczenie zarówno w sferze poznawczej, jak i emocjonalnej.

Wszelkiego rodzaju wycieczki stanowią integralny składnik edukacji, rozbudzają zainteresowania intelektualne, zachęcają do samokształcenia i samowychowania, inspirują do poznania kultury i cywilizacji, dają szansę na wymianę doświadczeń i tworzenie więzi społecznych, zaspokajają też potrzeby zdrowotne, rekreacyjne i edukacyjne. (Turos, 2003)

L. Turos samokształceniem turystycznym nazywa zespół i układ celów, działań i efektów, dzięki którym turysta może zgodnie ze swoimi potrzebami i zainteresowaniami samodzielnie wykorzystać każdą sytuację turystyczną w celu poszerzenia i wzbogacenia swojej wiedzy o otaczającym świecie. Tego typu edukacja ma charakter wielokierunkowy, ponieważ obejmuje wiedzę o przyrodzie, społeczeństwie i kulturze.

Turystyka, zdaniem L. Turosa, łamie bariery miedzy ludźmi i narodami, grupami etnicznymi i wyznaniowymi. Uczy tolerancji, dialogu różnych kultur, pozwala odrzucać 
stereotypy, weryfikuje wcześniej nabytą wiedzę, rozwija zainteresowanie kulturą, historią, cywilizacją, naturą i społeczeństwem. Pogłębia współpracę w skali regionalnej, narodowej i międzynarodowej oraz wymianę doświadczeń. Podróże przyczyniają się do uspołecznienia ludzi i ich humanizacji.

Turystyka w procesie kształcenia pełni następujące funkcje:

$\Rightarrow \quad$ Dostarcza wrażeń, spostrzeżeń i pojęć o otaczającym świecie; tworzy spójny i sprawdzony obraz rzeczywistości przyrodniczej, kulturowej i ludzkiej,

$\Rightarrow$ Rozbudza potrzebę badania, poznawania i penetrowania świata, potrzebę rozumienia go i racjonalnego w nim działania,

$\Rightarrow \quad$ Wzbogaca poczucie sensu życia, pokazuje bogactwo, ogrom i złożoność świata przyrody, kultury i społeczeństwa,

$\Rightarrow \quad$ Ukazuje tereny ludzkiej aktywności,

$\Rightarrow \quad$ Ukazuje urodę świata,

$\Rightarrow$ Daje szansę porównania własnego kraju, jego gospodarki, kultury, życia społecznego z innymi państwami,

$\Rightarrow$ Zachęca do studiowania opracowań, materiałów naukowych, przewodników, itp.,

$\Rightarrow \quad$ Promuje zdrowy styl życia,

$\Rightarrow \quad$ Wpływa na polepszenie zdrowia,

$\Rightarrow \quad$ Kształci postawy patriotyzmu,

$\Rightarrow$ Wzmacnia tożsamość narodową,

$\Rightarrow \quad$ Integruje ludzi, społeczności, narody. (Niedzielska, 2001/2002)

Krajoznawstwo i turystyka są jedną z najbardziej atrakcyjnych form kształcenia. Bezpośredni kontakt ze środowiskiem pozwala na poczynienie obserwacji i spostrzeżeń oraz rozszerzenie wiedzy. Zdaniem E. Niedzielskiej, turystyka spełnia wiele funkcji, najczęściej są to następujące:

$\Rightarrow \quad$ Funkcja informacyjno-poznawcza,

$\Rightarrow$ Funkcja wychowawczo-ideowa i społeczno-moralna,

$\Rightarrow$ Funkcja polityczno-gospodarcza,

$\Rightarrow$ Funkcja rozwoju kulturalno-estetycznego,

$\Rightarrow$ Funkcja ekonomiczna,

$\Rightarrow$ Funkcja rekreacyjno-zdrowotna,

$\Rightarrow \quad$ Funkcja poznawania i ochrony środowiska. (Niedzielska, 2001/2002)

Zdaniem K. Przecławskiego turystyka przyczynia się do rozwoju wielu pozytywnych procesów społecznych. Następuje rozwój gospodarczy miejscowości, regionów i krajów. Konsekwencją turystyki przyjazdowej jest proces bogacenia się ludności, rozwój oświaty, zwiększająca się ruchliwość społeczeństwa. Następują procesy integracji ze światem zewnętrznym. Pogłębia się proces rozwoju świadomości narodowej. Poprzez turystykę dokonuje się również zderzenie kultur: ogólnonarodowej z regionalną, wiejskiej z miejską. Konsekwencją rozwoju turystyki jest też rozwój języka ludności terenów odwiedzanych przez podróżnych (powstają nowe wyrażenia, zwroty, itp.). następują zmiany w strukturze społecznej: zawodowej, dochodowej, wykształcenia, klasowo-warstwowej. Dokonują się też 
przemiany w systemie wartości i zachowaniu mieszkańców danego regionu. (Przecławski, 1979)

Uprawianie turystyki kształtuje postawę aktywności, uczy pokonywania problemów, zwiększa zdolność do adaptacji w nowych warunkach i sytuacjach, przyzwyczaja do zmian, stwarza możliwość większej koncentracji w poznawaniu i przeżywaniu różnych wartości, uwrażliwia na piękno, stymuluję pracę twórczą, pogłębia więzy rodzinne i społeczne. Należy wspomnieć, iż w czasach, kiedy tworzyły się zarysy naukowych koncepcji pedagogicznych, m.in. J. H. Pestalozziego, J. A. Kamieńskiego, J. Locke'a czy J. J. Rouseau, zaczęto eksponować wychowawczą rolę środowiska. (Domżał, 2008)

Zdaniem K. Przecławskiego, wychowawcze skutki turystyki odnoszą się zarówno do samych podróżnych, jak i ludności zamieszkałej na terenach odwiedzanych.

Według H. Piętki (1957), celem wychowania przez turystykę jest „poznawanie obcej zbiorowości i jej zrozumienie". Dokonuje się to poprzez wzajemne zbliżanie się obcych środowisk, zbliżanie się do siebie obcych ludzi, czy rozbudzanie i umacnianie dążenia do pokoju. (Piętka, 1957)

Walory wychowawcze podróży doceniał już w starożytności Platon, Ciceron. O chęci poznania charakterów i obyczajów innych narodów mówił Michel Montaigne. Kształcenie umysłów podkreślał Descartes. Podróże stanowią też uzupełnienie edukacji, jak mawiał John Locke. Turystykę doceniał także Jan Amos Komeński.

Współcześnie w dobie masowego rozwoju turystyki, rośnie jej znaczenie wychowawcze. Podróże wszechstronne oddziaływują na rozwój osobowości człowieka, stwarzają możliwość zaspokojenia jednej z podstawowych potrzeb jaką jest potrzeba poznawcza. Turystyka daje poczucie wyzwolenia, umożliwia też realizację potrzeby poszukiwania nowości, nowych doświadczeń, stanowi bodziec do twórczej pracy.

Współcześnie wychowanie postrzegane jest jako „pogłębiona aktywność wychowawcza obejmująca również odpowiedzialne kształtowanie środowiska społeczno-kulturowego”. Jak twierdzi U. A. Domżał, ", wychowanie nie służy jedynie dobru jednostki, ale także koreluje z potrzebami życia społecznego". Przeobrażenia cywilizacyjne wyznaczają edukacji nowe zadania, zmuszają do szukania nowych rozwiązań po to, by wychować człowieka aktywnego, wszechstronnego, mobilnego, ze zdolnościami do adaptacji. (Domżał, 2008)

K. Wojciechowski podkreśla społeczne funkcje podróży. Zdaniem autora, wycieczki krajowe i zagraniczne przyczyniają się do kształtowania nowoczesnej świadomości patriotycznej, opartej na rzeczywistej znajomości osiągnięć społeczno-gospodarczych danego kraju, na poznaniu jego walorów krajobrazowych, architektonicznych. Podróże pełnią też ważne funkcje integracyjne, poznawcze i wychowawcze. (Wojciechowski, 1986) Są też środkiem kształtowania uczuć oraz emocjonalnej warstwy psychiki człowieka, pogłębiają procesy twórcze i samokształceniowe. (Półturzycki, 1967) Zapobiegają poczuciu osamotnienia, dowartościowują. Mogą pełnić funkcje autokreacyjną i psychoterapeutyczną. (Zawadzki, 2001)

Zdaniem A. Matuszczak działalność krajoznawczo-turystyczna może być:

- Atrakcyjnym spędzeniem czasu,

- Służyć rozrywce,

- Wzbogacać osobowość,

- Umożliwiać poznanie kraju, świata i siebie.

Według autorki, walory poznawcze, to nie tylko przygoda i przyjemność, ale także atrakcyjna, swobodna i beztroska nauka. Wycieczki pozwalają pogłębić wiedzę, poznać region 
pod względem historycznym i etnograficznym, dostrzec walory przyrodnicze. Mówiąc o wychowawczych celach turystyki, A. Matuszak ma na myśli:

- Wdrażanie do poznania kraju oraz działań na rzecz ochrony naturalnego środowiska,

- Zachęcanie do aktywnego wypoczynku,

- Kształtowanie postaw odpowiedzialności za swoje czyny i podejmowane decyzje,

- Doskonalenie umiejętności współpracy,

- Ułatwienie nawiązywania kontaktów międzyludzkich,

- Wzmacnianie przyjaźni,

- Kształtowanie kultury osobistej. (Matuszak, 2002)

Zdaniem K. Przecławskiego wychowawcze funkcje turystyki zależą od tego, kim jest podróżny. Głównie chodzi o wiek, płeć, wykształcenie, zamożność, pełnione role społeczne, stan zdrowia, wcześniejsze doświadczenia związane podróżowaniem. Autor wymienia sześć podstawowych dziedzin socjalizacyjnego (wychowawczego) oddziaływania aktywności turystycznej. Zdaniem autora turystyka:

$>\quad$, może być środkiem poznania rzeczywistości,

> Może kształtować określone postawy wobec rzeczywistości,

$>\quad$ Może być środkiem kształtowania uczuć,

$>$ Stwarza możliwość działania twórczego,

$>$ Przyczynia się do potęgowania zdrowia,

> Może być czynnikiem resocjalizacji”. (Przecławski, 1979)

Współcześnie, dzięki turystyce możliwie jest spostrzeganie świata jako „globalnej wioski”, czy też „globalnego osiedla” oraz jako kulturowej cywilizacyjnej społecznej, demograficznej i gospodarczej całości Rozwój turystyki pozwala na ujmowanie problemów własnej pracy zawodowej, środowiska, regionu, kraju na tle ogólnej sytuacji w innych państwach, czy na innych kontynentach. (Turos, 2003)

Zdaniem L. Turosa turystyka jest formą aktywności pozwalająca zaspokoić pragnienie osobistego kontaktu $\mathrm{z}$ autentykiem. Powyższa potrzeba rozbudzona i wzmacniana przez edukację, przejawia się chęcią poznania różnorodnych zabytków cywilizacji i kultury, osobliwości natury, wybitnych jednostek, dzieł sztuki i architektury. Według autora, nasza cywilizacja ze względu na rozmiary zjawiska turystyki i jej swoistość, często nazywana jest cywilizacją turystyki i podróży. Turystyka daje szansę pragnienia zetknięcia się z tym, co nieznane, egzotyczne, oryginalne, rzadko spotykane, poruszające wyobraźnią, wprowadzające jednostkę w inny świat. Turystyka stwarza wiele możliwości do samorealizacji. Pełni ważną funkcję w kształtowaniu światopoglądu, pobudza do refleksji, aktywizuje intelektualnie.

Turystyka to doświadczenie poznawcze, emocjonalne, estetyczne, społeczne i moralne, dzięki któremu można obiektywnie ocenić zachowania własne i innych, lepiej programować działalność społeczną i życie osobiste oraz w sposób bardziej racjonalny rozwiązywać problemy lokalne, czy natury ogólnej. Dzięki turystyce, człowiek staje się aktywnym uczestnikiem kultury i cywilizacji ogólnoludzkiej, korzysta z jej owoców.

W literaturze filozoficznej i pedagogicznej znajdujemy wiele refleksji na temat podróżowania. W poszczególnych epokach przypisywano wędrówkom różne wartości. 
Przedstawiciele starożytności (Cicero, Cattukus, Horatius) podkreślali uznanie dla autentyzmu obiektów i doświadczeń podróżniczych. Wyrażali podziw dla walorów poznawczych i wpływu podróży na osobowość ludzką i kulturę. Zwracali uwagę na znaczenie swoistego przekazywania historycznych treści i konkretność miejsc związanych z historią zostały przez Cycerona podniesione do rangi wartości, która uzasadniała ich humanistyczny sens.

Horacy, tak jak i Cyceron, wskazywał na konieczność poznawania obyczajów innych ludzi, co świadczy, że już starożytni myśliciele odkryli psychologiczne aspekty podróży.

Powyższe wartości zostały $\mathrm{W}$ pełni potwierdzone przez praktykę wędrówek w późniejszych epokach i doświadczeniach kolejnych pokoleń.

Jak twierdzi L. Turos mimo różnic w warunkach historycznych, określonych sytuacji społecznych i cywilizacyjnych, pewne potrzeby psychiczne i doświadczenia tych pokoleń zachowały trwałą, nieprzemijającą wartość. Uwzględniając fakt, że w rozwoju kultury i wychowania działa prawo kontynuacji idei i doświadczeń, można mówić o ponadczasowym charakterze przeżyć związanych z oglądaniem miejsc, w których żyli twórcy zarówno historii, jak i kultury. (Turos, 2003)

Poglądy Cycerona mogą stać się współcześnie pewnym drogowskazem dla podróżnych. Wędrówki szlakami historycznych miejsc pełnią szczególną rolę w kształtowaniu świadomości kulturalnej człowieka.

Renesans wniósł do kultury ogólnoludzkiej pewne trwałe wartości, np. zamiłowanie do poszukiwania czegoś nowego, nieznanego, szczególnie ważnego dla człowieka. Chodzi też o zaspokojenie potrzeby poznania, przeżyć estetycznych, różnorodności doświadczeń. Zrywano $\mathrm{z}$ jednostronną średniowieczną kontemplacją życia duchowego, odświeżając tym samym wrażliwość oraz przywracając wiarę w sens egzystencji.

Epoka renesansu wyzwoliła głód wiedzy o świecie oraz silne dążenie do poszukiwania rzeczy nowych. Podróż stała się źródłem edukacji, poszerzania horyzontów, przygodą intelektualną.

W renesansie rozumiano naturę ludzką, którą ujmowano zarówno w skali społecznej, jak i indywidualnej. Potwierdzeniem są refleksje najwybitniejszych przedstawicieli tego okresu. Uznano za laickie, słuszne i wartościowe pragnienie zdobycia wiedzy o przyrodzie, kulturze i społeczeństwie.

Należy zaznaczyć, iż dawniej podróże, w stosunku do współczesnego ruchu turystycznego, były nieliczne, najczęściej dostępne dla wąskiej i zamożnej grupy społecznej. Odbywano je w różnych celach: edukacyjnych, religijnych, handlowych, dyplomatycznych, dla przyjemności itp. Dla rozwoju kultury społecznej miały istotne znaczenie, tworzyły prototypy $\mathrm{i}$ wzorce podróżowania. Jednym $\mathrm{z}$ podstawowych motywów wędrówek było poznawanie świata.

Przedstawiciele polskiego Renesansu (np. A. Frycz Modrzewski, M. Rej, Ł. Górnicki, P. Stoiński zw. Pierre Statorius Stoiński, J. Kochanowski, S. F. Klonowicz, J. Bielski) w swoich wypowiedziach ukazali szczególny system wartości. Czuli się odpowiedzialni za losy własnego kraju. Podróże traktowali jaką doskonałą okazję do podpatrywania innych narodów, szukania wartościowych rozwiązań społecznych, przyswajania obyczajów, praw i użytecznych metod wzmacniających gospodarkę, obronność kraju i podnoszących kulturę. Mówili nie tylko o utylitarnych celach wędrówek. Podróże miały być przede wszystkim szkołą wychowania obywatelskiego, źródłem mądrości społecznej i politycznej.

M. Rej zachęcał do obserwowania zwyczajów obcych narodów, podpatrywania ich metod gospodarowania. 
P. Stoiński, zwany Młodszym (znany także jako Pierre Statorius junior), chwalił zwiedzanie krajów i miast. Również zalecał poznanie zwyczajów cudzoziemców oraz przypatrywanie się nowinkom technicznym, czy działaniu różnych urządzeń.

Pisarze i myśliciele polskiego Renesansu ostrzegali też przed negatywnymi skutkami podróży. Bielski, Klonowicz, Górnicki twierdzili, że wędrówki dla części podróżnych mogą być okazją do demoralizacji, pijaństwa i warcholstwa. Tego typu przestrogi wynikały z troski obywatelskiej o zachowanie dobrego imienia Polaka i narodu polskiego za granicą.

Jednak najpełniejszą koncepcję wychowania przez podróże zaproponował wybitny czeski pedagog Jan Amos Komeński (1592-1670). Odwołując się do własnych doświadczeń podróżniczych oraz literatury i rozmów z wybitnymi myślicielami, stworzył określony system wychowania przez podróże. Znajdujemy go np. w dziele „De rerum humanorum emandatione consultatio catholica” („Powszechna narada o naprawie rzeczy ludzkich”), w którym podnosił samokształceniowe wartości podróżowania. (Turos, 2003)

J. A. Komeński uznał integralność świata jako obiektu poznania i dostrzegał w nim źródło mądrości życiowej. Według autora, wędrówka jest okazją do pogłębionej refleksji na temat wychowawczej roli podróży. Wartościom edukacyjnym poświęcił osobną rozprawę pt.: „Regule vitae sapientis”, wydaną w roku 1658.

Współczesnego odbiorcę zaskakuje w poglądach Komeńskiego nowoczesne ujmowanie roli turystyki i widzenie jej ścisłego związku z edukacją narodową i postępem społecznym. Pedagog uważał, że dzięki upowszechnieniu podróżowania jako zorganizowanej przez państwo formy zdobywania wiedzy o innych krajach, nastąpi poprawa stosunków społecznych, odnowa życia narodowego oraz podniesienie kultury i gospodarki. (Turos, 2003)

Zdaniem Komeńskiego, dobre przykłady, wzorce i doświadczenia wyniesione z podróży, pobudzą do myślenia, przyczynią się do uzdrowienia życia społecznego. Komeński, w przeciwieństwie do wielu swoich poprzedników, traktuje podróż w szerszym kontekście, jako zagadnienie ogólnospołeczne i ogólnopaństwowe, a nie jako przyjemność czy zamiłowanie. Uznaje podróżowanie za niezwykle cenne narzędzie działania oświatowego, przedłużenie procesu kształcenia, możliwości łączenia teorii $\mathrm{z}$ praktyką. Widzi również ostro i wyraźnie humanistyczne wartości podróżowania. Dostrzega walory estetyczne, intelektualne i poznawcze.

Konkretne wskazówki metodologiczne na temat przygotowania się do podróży, samego jej przebiegu i spożytkowania doświadczeń zawarł w dziele pt. „O ogólnej naradzie o naprawie rzeczy ludzkich". Zalecał uczenie się języków obcych, aby lepiej poznać zwiedzany kraj oraz studiowanie historii. Radził korzystać z map i przewodników. Zachęcał do pisania dzienników podróży i dbałości o bezpieczeństwo w czasie wędrówek. Troska o powyższe potrzeby stanowi najlepszy dowód mądrości Komeńskiego. Jego idee do dziś są aktualne i trwałe.

Warto wspomnieć, iż w roku 1625 powstała rozprawa o tym, jak należy podróżować, autorstwa Polaka P. Mieszkowskiego: „Institutio peregrinationum peregrinantibus peroportuna” (,Zasady podróży dla mających odbyć podróż”). Główny postulat pracy, to hasło: „Podróżowanie niech będzie wychowawczynią obywatelskich obyczajów i matką prawdziwej mądrości”. (Wojciechowski, 1986)

Wybitny filozof J. Locke, twierdził, że wykształcenie szkolne należy uzupełniać wiedzą zdobytą przez wyjazdy do obcych krajów. Podróże, zdaniem myśliciela prowadzą do: „powiększania mądrości i roztropności przez zaznajomienie się i obcowanie z ludźmi o usposobieniach, zwyczajach i sposobie życia różniących się nawzajem od siebie". (Locke, 1984) 
Podobnie pisał J. J. Rouséau, a jego powieść pt.: „Nowa Heloiza”(1760), uznano za poważny wkład w rozwój turystyki w Szwajcarii.

Z kolei negatywne stanowisko w sprawie podróży wyraził, np. szkocki biskup z XVIII wieku - Gilbert Burnet, dla którego podróż może się przyczynić do ateizmu, poddania się wpływom zwyczajów, zachowań innych narodów. (Locke, 1984)

W oświeceniu model kultury podróżniczej został określony przez prawnika J. Szymanowskiego, pełniącego funkcje sekretarza Zygmunta Augusta, autora pracy o zasadach, celach i walorach podróży: „Wyprawa na wojaż”. Szymanowski uważał wypoczynek, zdrowie, rozrywkę, dopełnienie edukacji i wartości poznawcze za ważne cele i rezultaty podróżowania”. (Turos, 1977)

Wielkie zasługi dla rozwoju turystyki położył S. Staszic, nazywany „ojcem krajoznawstwa polskiego". (Wojciechowski, 1986)

Romantyzm akcentował znaczenie podróży jako inspiracji i terenu obserwacji szczególnie ważnej w procesie twórczości artystycznej. XIX stulecie to dalsze pogłębianie refleksji na temat roli wędrówki. Pisarze i myśliciele wyrażają troskę o wykorzystanie doświadczeń podróżnych dla dobra ojczystego kraju. W turystyce dostrzega się walor patriotyczny i obywatelski. Postuluje się prymat turystyki krajowej (Gloger, Orzeszkowa, Kraszewski).

W czasach niewoli narodowej zaznacza się nurt myślenia o społecznej roli podróży. W okresie Pozytywizmu traktuje się podróż nie tylko jako źródło doświadczeń, ale i źródło inspiracji twórczej, silnie działającej na wyobraźnię. Doświadczenia podróżnicze stanowią bazę do przeżyć intelektualnych i estetycznych oraz duchowych.

$\mathrm{Na}$ edukacyjną rolę podróży zwraca uwagę M. Orłowicz (1881-1959), pionier polskiej turystyki i krajoznawstwa, autor przewodników i prac publicystycznych, działacz społeczny w zakresie rekreacji i sportu. Propagował on turystykę będącą świadomym wyborem człowieka, decydującego się na porzucenie osiadłego trybu życia na rzecz zwiedzania świata, poznawania nowych kultur, języków, zagłębiania historii, sztuki ludowej i geologii, itp. Był miłośnikiem wędrówki opartej na głębszym przeżywaniu piękna natury, fascynacji zabytkami i osobliwościami przyrody. (Targosz, 2002)

Zdaniem Orłowicza, podróże krajoznawcze umożliwiają zwiedzanie i wielostronne poznawanie kultur różnych regionów kraju, mentalności grup etnicznych, folkloru, ciekawych miejsc, zabytków architektonicznych, pomników kultury i sztuki.

W wieku XX powstało wiele koncepcji odnoszących się nie tylko do indywidualnych doświadczeń podróżnych, ale również uwzględniających problematykę masowego ruchu turystycznego. Podróżowanie traktowane jest jako ruch społeczny, który otwiera niewyczerpane możliwości poznania świata i uzyskanie tą drogą kształcących przeżyć. Oczywiście, rozwój turystyki wiąże się z rozwojem kultury i cywilizacji. Podróże stanowią istotny element samokształcenia i doskonalenia osobowości, są ważnym źródłem wiedzy o świecie, stymulują aktywność poznawczą.

Według amerykańskiego andragoga C. Houle’a (1984), podróż należy postrzegać jako sytuację edukacyjną, kształtującą wiedzę, pobudzającą autoedukację, wpływającą na emocje i doznania, wnoszącą nowe doświadczenia. Zdaniem autora, kontakt z oryginalnym dziełem, dostarcza różnorodnych przeżyć w wymiarze artystycznym i duchowym. Daje szansę konfrontacji wiedzy i wyobrażenia z zastaną rzeczywistością.

C. Houle, mówiąc o roli podróży, stwierdził, iż ,efekt edukacyjny podróżowania polega nie na podróżowaniu, na samym doświadczeniu, lecz na tym co podróżujący w to wnosi”. (Houle, 1984) 
Według O. Czerniawskiej podróż podlega czasowi historycznemu, który nadaje jej znaczenie w wymiarze pokolenia. (Czerniawska, 2001)

Zdaniem Z. Krawczyka wzajemne relacje zachodzące między naturą i kulturą nie tylko w wymiarze obiektywnym, ale i osobowościowym, widziane kiedyś w kategoriach antynomicznych, współcześnie jawią się coraz częściej jako rozwiązywalne w oparciu o zasady ustępstw i kompromisów.

Rygorystycznie ujmowaną jednowymiarowość ewolucji świata zastąpiono dzisiaj względną wymiarowością, przy jednoczesnej aprobacie biwalencji postaw i zachowań, nie tylko w sensie grupowym, ale i indywidualnym.

Przyspieszenie tempa rozwoju cywilizacyjnego, degradacja środowiska naturalnego skłania do poszukiwania rozwiązań o charakterze aksjologicznym. Zaczęto doceniać wartość życia i zdrowia, rośnie znaczenie kreacji i rekreacji ciała w ogólnych koncepcjach socjalizacji, akulturacji i wychowania. W związku z tym masowo rozwijają się nowe zawody, specjalizacje i usługi związane m.in. z podróżami, rekreacją i obsługą ruchu turystycznego. (Krawczyk, 2007)

Ernst Cassirer (1971), stwierdził, że na dziedzictwo kulturowe człowieka składają się : język, mit, religia, sztuka, nauka i historia. Jest to świat symboli, który przeciwstawia się całkowicie światu fizycznemu. Dzięki niemu człowiek ,tak bardzo owinął się w formy językowe, w obrazy artystyczne, w mityczne symbole lub religijne obrządki, że nie potrafi już niczego zobaczyć, ani poznać inaczej, jak za pomocą tego sztucznego środka." Zdaniem autora, kluczem do zrozumienia istoty człowieka nie jest poszukiwanie jego naturalnych właściwości, ale uwikłania w sferę kultury, określającej bez reszty jego „ludzki” wymiar. Podstawową kategorią bytu jest świat wartości. (Cassirer, 1971)

Jak twierdzi H. M. Kriese podróże kształcą przypuszczalnie tylko tego, kto już posiada wykształcenie, względnie tego, kto poprzez intensywne czytanie potrafi się do nich przygotować i w sposób kognitywny umie ocenić przeżycia z podróży oraz przetworzyć je pod względem psychiczno-intelektualnym. (Kriese, 2001)

Zdaniem R. Winiarskiego dzięki turystyce, rekreacji, aktywności fizycznej, człowiek ma możliwość zaspokajania swoich potrzeb, zainteresowań i aspiracji. Samorealizacja jednostki w określonym kierunku jest uzależniona od jej aktualnych potrzeb, a także od ogółu dyspozycji motywacyjnych, wyrażających gotowość do podejmowania określonych form zachowań, które autor nazywa strukturą motywacji ukształtowaną w dotychczasowym życiu człowieka w toku jego rozwoju biologiczno społecznego. (Winiarski, 1988)

Turystyka jest narzędziem rozwijającym osobowość, sprzyja więc samokształceniu. Podróż staje się przygodą intelektualną. Uczy określonych wzorów przeżywania, myślenia i zachowania społecznego; uwalnia od mitów, stereotypów. Pozwala unowocześnić i uaktualnić wiedzę. (Turos, 2003)

Podróże mają wpływ na wszechstronny rozwój jednostki: fizyczny, psychiczny, kulturalny i intelektualny. Zdaniem B. Juraś-Krawczyk generalnie wzmacniają rozwój emocjonalny człowieka. Są źródłem wzbogacania poczucia sensu egzystencji, ukazują piękno świata, wzmacniają uczucie afirmacji życia, pobudzają do samokształcenia i samowychowania. Według autorki, podróże ,poszerzają perspektywę życia, zwłaszcza ludzi starszych, w przypadku których zaspokajają potrzebę afiliacji i pełnią funkcje terapeutyczną". (JuraśKrawczyk, 2001)

Zdaniem B. Juraś-Krawczyk, podróże można traktować jako nietypową formę edukacji, która przyczynia się do: 


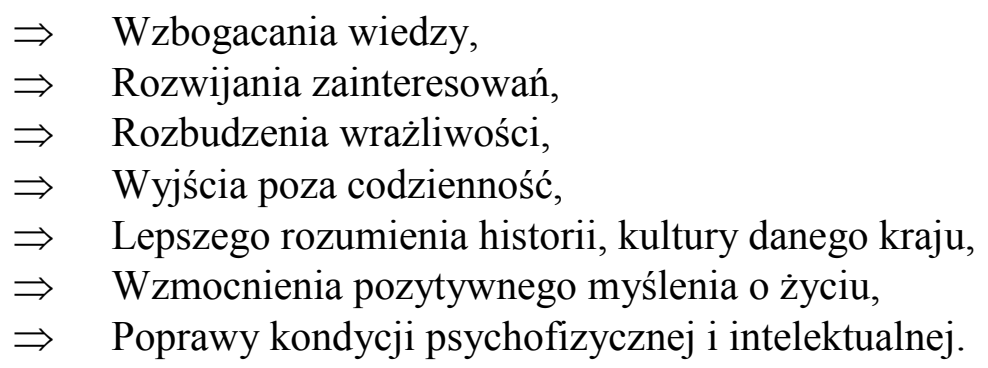

Podobną opinię wyraża G. Orzechowska, jej zdaniem podróże na trwałe pozostają w pamięci, szczególnie u osób starszych. Są tematem rozmów, „inspirują do poszukiwań i zgłębiania innych obszarów wiedzy, mobilizują do organizowania dalszych wypraw, a przede wszystkim aktywizują". Zdaniem autorki, każda aktywność osób starszych przeciwdziała regresowi i utracie sił psychofizycznych, czy intelektualnych. (Orzechowska, 2001)

\section{CONCLUSIONS}

Podróż jest niezastąpioną okazją poszerzania wiedzy, pogłębia ona motywację do samokształcenia, tworzy warunki dla rozwoju osobowości. Jednym z aspektów podróżowania czy turystyki jest podróż naukowa, podejmowana dla zdobycia określonej wiedzy, wykształcenia, własnej edukacji, czyli w celu poznawczym, studiowania, pracy twórczej, uczestnictwa w konferencjach. Uczestnictwo w podróży jest nie tylko źródłem poznania naukowego i doskonalenia się, ale i źródłem różnorodnych przeżyć intelektualnych, moralnych, estetycznych i emocjonalnych. Podróże to ważny element samokształcenia. Zdobyta wiedza może pomóc $\mathrm{w}$ dalszej pracy naukowo-badawczej, pozwala łączyć teorię z praktyką, umożliwia zdobywanie nowych umiejętności zawodowych i pozazawodowych, doskonali znajomość języków obcych, przybliża różnorodność kultur, wnosi nowe doświadczenia.

Edukacja turystyczna daje szansę udziału w dialogu kultur, wychowuje humanistycznie, przełamuje bariery nieufności miedzy ludźmi, narodami i społeczeństwami różnych regionów świata. Podróż, niezależnie od czasu, miejsca, celu i innych okoliczności towarzyszących wędrówce, daje szansę na rozwój.

Podróże wpływają na wszechstronny rozwój człowieka, stanowią źródło wiedzy. Wzmacniają poczucie sensu życia, aktywizują, pobudzają twórczo i intelektualnie. Poszerzają perspektywę widzenia świata, integrują społecznie, doświadczają edukacyjnie. Oferują bogactwo doznań: estetycznych, artystycznych, duchowych i relaksacyjnych.

\section{References}

[1] Cassirer E., Esej o człowieku, Wydawnictwo Czytelnik, Warszawa 1971.

[2] Czerniawska O., Podróże jako projekt edukacyjny, [w:], O. Czerniawska, B. JuraśKrawczyk (red.), Podróże jako projekt edukacyjny, WSHE Łódź, 2001.

[3] Domżał U. A., Idee koncepcji Marii Montessori we współczesnej edukacji dziecka, [w:], U. Ordon, A, Pękala (red.), Tradycja i nowoczesność w edukacji przedszkolnej $i$ wczesnoszkolnej, Wyd., A J D w Częstochowie, Częstochowa 2008. 
[4] Domżał U. A., Wybory moralne nauczycieli, Edukacja zdrowotna, Nr1, Półrocznik naukowy WSEZ w Łodzi, Łódź 2009, Vol. 6.

[5] Domżał Z., Formy opieki nad dzieckiem w XX leciu międzywojennym, [w:], Tradycja $i$ nowoczesność w edukacji przedszkolnej $i$ wczesnoszkolnej, U. Ordon, A. Pękala (red), Wyd. A J D, Częstochowa 2008.

[6] Dzięgielewska M., Podróże naukowe jako forma zdobywania wiedzy [w:], O. Czerniawska, B. Juraś-Krawczyk (red.) Podróże jako projekt edukacyjny, WSHE, Łódź 2001.

[7] Gębora A. K., Wykorzystanie Internetu we współczesnej edukacji-szanse i zagrożenia, Edukacja zdrowotna, Nr 1, Półrocznik naukowy WSEZ w Łodzi, Łódź. 2009.

[8] Houle C., Patterns of Learning, (polski tytuł „Wzory uczenia się” rozdział: Florencjabadania źródłem centrum kultury.) Londyn 1984.

[9] Juraś-Krawczyk B., Podróże rodzinne jako stymulacja rozwoju, [w:] O. Czerniawska, B. Juraś-Krawczyk (red.) Podróże jako projekt edukacyjny, WSHE, Łódź 2001.

[10] Juraś-Krawczyk B., Wprowadzenie, [w:], O. Czerniawska, B. Juraś-Krawczyk (red.), Podróże jako projekt edukacyjny, WSHE, Łódź 2001.

[11] Köb Susanne - Filozofia podróży, Wyd. Focus Giessen, Niemcy 2005.

[12] Krawczyk Z., Człowiek i natura. Filozofia i ideologia taternika i marynistyczna Mariusza Zaruskiego,[w:], Z. Krawczyk, Natura, kultura, sport, PWN, Warszawa 1970.

[13] Krawczyk Z., O turystyce i rekreacji, Studia i szkice, Wydawnictwo ALMAMER Wyż. Szkoły Ekonomicznej, Warszawa 2007.

[14] Kriese H. M., Podróżowanie im edukacja-asocjacje i aspekty, [w:], O. Czerniawska, B. Juraś-Krawczyk (red.), Podróże jako projekt edukacyjny, WSHE Łódź, 2001.

[15] Locke J., Myśli o wychowaniu, (tłum.) F. Wnorowski, Wstęp: K. Mrozowska, Ossolineum, Wrocław 1959.

[16] Matuszak A., Refleksje o młodzieży wędrującej...Krajoznawstwo i turystyka poprzez zdobywanie odznak turystyki kwalifikowanej, Geografia w Szkole, Nr 4, 2002.

[17] Miazgowski B., Kalos k'agatos. Wstep, [w:], M. Zaruski, Wśród wichrów i fal, Sit, Warszawa, 1958.

[18] Niedzielska E., Rola Kadry w organizowaniu obozów wędrownych oraz ich znaczenie dydaktyczno-wychowawcze, Rocznik Naukowy, Tom IV 2001/2002 WSHiG, Poznań 2001.

[19] Orkan Z., Z nad Battyku, [w:] Warta (Studia, listy, szkice), Lwów, 1926.

[20] Orzechowska G., Seniorzy o „podróży swojego życia”, [w:], O. Czerniawska, B. Juraś-

[21] Krawczyk (red.), Podróże jako projekt edukacyjny, WSHE, Łódź 2001.

[22] Piętka H., Potrzeba rozwinięcia zmystu badawczego wśród turystów, Ruch Turystyczny $\mathrm{Nr} 2,1957$.

[23] Półturzycki J., Samokształcenie przez turystykę i krajoznawstwo, Nauczyciel i Wychowanie, Nr 4, 1967.

[24] Przecławski K. , Socjologiczne problemy turystyki, CRZZ, Warszawa 1979. 
[25] Sługocki J., M. Zaruski, a kwestia udziału społeczeństwa polskiego w budowie floty morskiej, Nautologia, $\mathrm{Nr}$ 4, 1988.

[26] Targosz R., Elementy edukacyjne w turystyce górskiej organizowanej przez Mieczysława Orłowicza w początkach XX wieku, [w:], W. Horyń, J. Maciejewski (red.),

[27] Nauczyciel andragog u progu XX wieku, Wyd. U. Wrocławski, Wrocław 2002.

[28] Turos L., Rola wychowania turystyki w dziejach myśli pedagogicznej, Oświata Dorosłych Nr 7-8, 1967.

[29] Turos L., Turystyka do krajów socjalistycznych jako czynnik samokształcenia nauczycieli, PWN, Warszawa 1977.

[30] Turos L., Turystyka edukacyjna i transgresja, Wszechnica Polska- Szkoła Wyższa TWP w Warszawie, Warszawa 2003.

[31] Winiarski R., Motywacja turystyczna: struktura i społeczne uwarunkowania, Problemy Turystyki, Nr 2, 1988.

[32] Wojciechowski K. (red.), Encyklopedia Oświaty i Kultury Dorostych, Ossolineum, Wrocław 1986.

[33] Wojciechowski K., Rozwój i znaczenie wychowawcze turystyki, Wychowanie Dorosłych, PWN, Warszawa 1966.

[34] Woźnicka E., Podróże rowerem po Europie jako inspiracja do uczenia się, [w:] O. Czerniawska, B. Juraś-Krawczyk (red.) Podróże jako projekt edukacyjny, WSHE, Łódź 2001.

[35] Zawadzki K., Funkcje podróży w życiu ludzi starszych [w:] O. Czerniawska, B. Juraś-

[36] Krawczyk ( red.), Podróże jako projekt edukacyjny, WSHE, Łódź 2001.

[37] Żeromski S., Wiatr od morza, Czytelnik, Warszawa 1955. 